\title{
Generalizirani Apolonijev problem
}

\author{
Antonija Guberina, Nikola Koceić Bilan
}

\section{Sažetak}

Apolonijev problem glasi: „Konstruiraj kružnicu koja dodiruje tri zadane kružnice". U uvodnom dijelu definiramo Apolonijev problem reda $n, n \in \mathbb{N}$ i na taj ga način generaliziramo. U nastavku rada posebno promatramo sve Apolonijeve probleme reda 1, 2 i 3 te određujemo geometrijsko mjesto središta (GMS) rješenja što je posebno interesantno za Apolonijeve probleme reda 2 jer se kao GMS javljaju konike pa na takav način dobivamo alternativnu definiciju konika. Važno je istaknuti da se kao GMS rješenja Apolonijevih problema reda 3, između ostaloga, javljaju presjeci 3 konike, 2 konike i pravca, koji su, protivno površnoj intuiciji, neprazni. Apolonijeve probleme reda $n \geq 4$ nije interesantno promatrati jer rješenja postoje samo u posebnim slučajevima. Također se iznosi ideja za daljne razmatranje stavljajući proizvoljni kut presjeka između traženih kružnica i zadanih $n$ elemenata umjesto kuta $\alpha=0^{\circ}$, kojega smo u radu promatrali.

Ključni pojmovi: Apolonijev problem, kružnica, elipsa, hiperbola, parabola, geometrijsko mjesto točaka

\section{Povijesni pregled}

Apolonije iz Perge (262. pr. n. e. - 190. pr. n. e.) grčki je matematičar nazvan „veliki geometar”. Studirao je u Aleksandriji, gdje je učio od Euklidovih sljedbenika, a radio u Efezu i Pergamu. U svom glavnom djelu Elementi konika u 15 knjiga temeljito je obradio teoriju presjeka stošca i ravnine i to čisto geometrijskim pristupom. Njegovi su rezultati bili toliko potpuni i podrobni da se današnja euklidska geometrija nije 
mnogo odmakla od njegovih spoznaja. Sačuvane su prve četiri knjige na grčkom, tri na arapskom prijevodu, dok su ostale izgubljene. Prvi je za konike upotrijebio nazive elipsa i hiperbola (naziv parabola je prvi upotrijebio Arhimed) i ustanovio da se sve tri vrste presjeka mogu dobiti presijecanjem stošca ravninom.

Uz Apolonija su vezani pojmovi kao Apolonijeva kružnica, Apolonijeva mreža i Apolonijev problem. Geometrijsko mjesto točaka za koje je omjer udaljenosti od dviju različitih točka konstantan je kružnica čije središte leži na pravcu $A B$ i prolazi točkama $M$ i $N$ na pravcu $A B$ koje dijele dužinu $\overline{A B}$ (iznutra i izvana) u danom omjeru. Kružnicu s tim svojstvom nazivamo Apolonijeva kružnica. U slučaju kada je omjer udaljenosti od dviju točaka jednak 1 , tada govorimo o simetrali dužine $\overline{A B}$.

Apolonijev problem je konstruktivni geometrijski zadatak što ga je prvi postavio i riješio Apolonije u djelu Elementi konika, a glasi:

Konstruiraj sve kružnice u ravnini koje dodiruju tri zadane kružnice.

Promatrajući uz kružnice još točke i pravce, Apolonijev problem možemo generalizirati na sljedeći način. Definirat ćemo Apolonijev problem reda $n$ : Neka je $M=\left\{K_{\infty}, P_{\infty}, T_{\infty}\right\}$ multiskup koji se sastoji od tri različita elementa beskonačne kratnosti: $K$ koji označava kružnicu, $P$ pravac i $T$ točku.

Apolonijev problem reda $n, n \in \mathbb{N}$ glasi:

\section{Konstruiraj kružnicu koja dodiruje $n$ zadanih elemenata mul- tiskupa $M$.}

Ukupan broj različitih problema za Apolonijev problem reda $n$ jednak je broju kombinacija s ponavljanjem $n$-tog razreda multiskupa od 3 različita elementa $\left(\begin{array}{c}3+n-1 \\ n\end{array}\right)$.

Za $n=1$ tražimo kružnicu koja dodiruje samo jedan od elemenata multiskupa $M$. Za ovaj red dobijemo tri različita problema $\left(\left(\begin{array}{c}3+1-1 \\ 1\end{array}\right)=\right.$ $\left.\left(\begin{array}{l}3 \\ 1\end{array}\right)=3\right)$ i to: „Konstruiraj kružnicu koja dodiruje zadanu kružnicu”; „Konstruiraj kružnicu koja dodiruje zadani pravac”; „Konstruiraj kružnicu koja prolazi zadanom točkom".

Za $n=2$ tražimo kružnicu koja dodiruje elemente određene kombinacijom s ponavljanjem reda 2 multiskupa $M$ i to njih šest $\left(\left(\begin{array}{c}3+2-1 \\ 2\end{array}\right)=\right.$ $\left.\left(\begin{array}{l}4 \\ 2\end{array}\right)=6\right):(K, K),(P, P),(T, T),(K, P),(K, T),(P, T)$. Npr. za kombinaciju $(K, K)$ problem glasi: „Konstruiraj kružnicu koja dodiruje dvije zadane kružnice”; za kombinaciju $(P, T)$ problem glasi: „Konstruiraj kružnicu koja dodiruje zadani pravac i prolazi zadanom točkom". 
Za $n=3$ tražimo kružnicu koja dodiruje elemente određene kombinacijom s ponavljanjem reda 3 multiskupa $M$ i to njih deset $\left(\left(\begin{array}{c}3+3-1 \\ 3\end{array}\right)=\right.$ $\left.\left(\begin{array}{l}5 \\ 3\end{array}\right)=10\right):(K, K, K),(P, P, P),(T, T, T),(K, P, T),(K, T, T),(P, T, T)$, $(K, P, P),(P, K, K),(P, P, T),(T, K, K)$. Npr. za kombinaciju $(K, K, K)$ imamo originalni Apolonijev problem: „Konstruiraj kružnicu koja dodiruje tri zadane kružnice"; za kombinaciju $(K, T, P)$ problem glasi: "Konstruiraj kružnicu koja dodiruje zadanu kružnicu, zadani pravac i prolazi zadanom točkom".

Za $n \geq 4$ problem je analogan prijašnjim slučajevima.

$\mathrm{U}$ ovom ćemo radu promatrati Apolonijeve problem reda $n=1,2,3$ i pokazati zašto nije interesantno promatrati Apolonijeve probleme reda većeg od 3. Zadaće je moguće riješiti euklidskom konstrukcijom (koristeći ravnalo i šestar) i to koristeći metodu inverzije. Međutim, u ovom se radu nećemo baviti takvim konstrukcijama, već samo analizom i razmatranjem ovih problema. Napose, određivanje središta rješenja uz korištenje metode geometrijskih mjesta točaka, donijet će nam vrlo zanimljive i vrijedne geometrijske rezultate i izvan konteksta konstruktivne geometrije. Pokazat će se da dobivena geometrijska mjesta središta rješenja većine Apolonijevih problema predstavljaju jednu koniku. Budući da će se, na takav način, svaka od konika pojaviti u barem jednom od problema, to se svaka od njih može alternativno definirati kao geometrijsko mjesto središta kružnica koje su rješenje određenog Apolonijevog problema što obogaćuje različite pristupe konikama ([2]) i pokazuje kako konike pronalazimo na prirodan način u svijetu koji nas okružuje. Isto tako, zanimljivo je kako zadaće konstruktivne geometrije ([3]), metode koje se sve manje koriste u redovitoj srednjoškolskoj nastavi matematike, mogu inicirati vrlo zanimljive probleme i njihova rješenja i izvan konstruktivnog konteksta.

U svrhu lakšeg praćenja teksta i njemu odgovarajućih slika, zadani elementi će biti plave, geometrijsko mjesto središta (GMS) kružnica odgovarajućeg Apolonijevog problema tamnozelene, rješenje konstruktivne zadaće crvene, geometrijsko mjesto središta Apolonijevog reda nižeg od promatranog zelene i pomoćni elementi crne boje. Euklidsku ćemo ravninu označavati s $\pi$, kružnicu sa središtem u $S$ radijusa $r$ s $k(S, r)$. Oznaku $E(A, B, a)$ rabiti ćemo za elipsu sa žarištima $A$ i $B$, te velikom poluosi $a$, oznaku $H(A, B, a)$ za hiperbolu sa žarištima $A$ i $B$, te realnom poluosi $a$, a oznaku $P(A, d)$ za parabolu sa žarištem $A$ i ravnalicom $d$.

Rad se zasniva na originalnim rezultatima iznesenim u diplomskom radu [1] studentice diplomskog studija Matematika i informatika; smjer nastavnički Prirodoslovno-matematičkog fakulteta u Splitu i njezina mentora Nikole Koceića-Bilana. 


\section{Apolonijev problem reda 1}

U ovom odjeljku razmatramo probleme koji spadaju u Apolonijev problem reda 1. Za svaki problem odredit ćemo geometrijsko mjesto središta svih rješenja.

1. Konstruiraj kružnicu koja prolazi zadanom točkom i odredi geometrijsko mjesto središta kružnica sa zadanim svojstvom.

Neka je $T$ zadana točka te $Q \neq T$ proizvoljna točka ravnine $\pi$. Kružnica s traženim svojstvom je $k=k(Q,|Q T|)$. Budući da je $Q$ proizvoljna točka ravnine, kružnica s traženim svojstvom ima beskonačno mnogo, a geometrijsko mjesto središta tih kružnica je $\pi \backslash\{T\}$.

2. Konstruiraj kružnicu koja dodiruje zadani pravac i odredi geometrijsko mjesto središta kružnica sa zadanim svojstvom.

Neka je $p$ zadani pravac i $O \notin p$. Iz točke $O$ spustimo okomicu $o$ na $p$ te sjecište tih pravaca označimo s $R(p \cap o=\{R\})$. Kružnica s traženim svojstvom je $k=k(O,|O R|)$. Budući da je $O$ proizvoljna točka ravnine, kružnica s traženim svojstvom ima beskonačno mnogo, a geometrijsko mjesto središta tih kružnica je $\pi \backslash p$.

3. Konstruiraj kružnicu koja dodiruje zadanu kružnicu i odredi geometrijsko mjesto središta kružnica sa zadanim svojstvom.

Neka je $k=k(S, r)$, gdje je $r$ proizvoljan pozitivan realan broj, zadana kružnica te $O$ proizvoljna točka iz $\pi \backslash k$. Neka je $S O \cap k=\left\{R_{1}, R_{2}\right\}$. Neka je $R_{1}$ s iste strane točke $S$ kao i $O$. Kružnica s traženim svojstvom je $k\left(O,\left|O R_{1}\right|\right)$. Budući da je $O$ proizvoljna točka ravnine, kružnica $\mathrm{s}$ traženim svojstvom ima beskonačno mnogo, a geometrijsko mjesto središta tih kružnica je $\pi \backslash k$.

\section{Apolonijev problem reda 2}

U ovom odjeljku razmatramo Apolonijeve probleme reda 2. Za svaki problem odredit ćemo geometrijsko mjesto središta svih rješenja.

1. Konstruiraj kružnicu koja prolazi dvjema zadanim točkama i odredi geometrijsko mjesto središta kružnica sa zadanim svojstvom.

Neka su $T_{1}$ i $T_{2}$ zadane točke te $T_{1} \neq T_{2}$. Budući da središte tražene kružnice treba biti jednako udaljeno od $T_{1}$ i $T_{2}$, to središte leži na simetrali dužine $\overline{T_{1} T_{2}}$, iz čega slijedi da tih kružnica ima beskonačno mnogo. Neka je $O$ proizvoljna točka simetrale dužine $\overline{T_{1} T_{2}}$. Tada je $k\left(O,\left|O T_{1}\right|\right)$ kružnica s traženim svojstvom. Dakle, geometrijsko mjesto središta rješenja je simetrala $s$ dužine $\overline{T_{1} T_{2}}$. 
2. Konstruiraj kružnicu koja dodiruje zadanu kružnicu i prolazi zadanom točkom te odredi geometrijsko mjesto središta kružnica sa zadanim svojstvom.

Neka je zadana točka $T$ i kružnica $k=k(S, r), r>0$, te neka se $T$ nalazi izvan $k$. Neka je $T_{1} \in k$ proizvoljna točka različita od dirališta tangenti iz točke $T$ na kružnicu $k$. Neka je $S T_{1} \cap s=\{O\}$, gdje je $s$ simetrala dužine $\overline{T T_{1}}$. Tada je $k(O,|O T|)$ kružnica s traženim svojstvom. Budući da je $T_{1}$ proizvoljna točka kružnice $k$, to takvih kružnica ima beskonačno mnogo i vrijedi ||$O T|-| O S||=|| O T\left|-\left(\left|O T_{1}\right|+\left|T_{1} S\right|\right)\right|=\left|T_{1} S\right|=r$, za svaki $T_{1} \in k$ i $O$ konstruiranu na prethodno opisani način. Taj zaključak nam govori da je geometrijsko mjesto središta kružnica s traženim svojstvom podskup hiperbole $H\left(T, S, \frac{r}{2}\right)$. Pokažimo drugu inkluziju, tj. neka je $O \in H\left(T, S, \frac{r}{2}\right)$. Tada je $r=|| O S|-| O T||$, odnosno $r=|O S|-|O T|$ ili $r=-|O S|+|O T|$ iz čega slijedi $|O S|=|O T|+r$ ili $|O T|=|O S|+r$. U oba slučaja je $k(O,|O T|)$ kružnica s traženim svojstvom (u prvom slučaju dodiruje zadanu kružnicu izvana, a u drugom iznutra) pa vrijedi da je hiperbola $H\left(T, S, \frac{r}{2}\right)$ podskup geometrijskih mjesta središta rješenja (Slika 1).

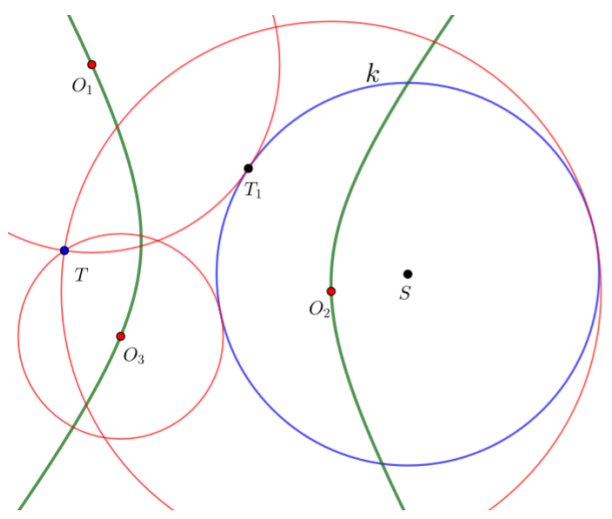

Slika 1

U slučaju kada se $T$ nalazi unutar kružnice $k$, geometrijsko mjesto središta kružnica s traženim svojstvom je elipsa $E\left(T, S, \frac{r}{2}\right)$ (Slika 2 . Naime, neka je $O$ središte kružnice $c=k(O, \rho)$ s traženim svojstvom koja $k$ dodiruje u $Q$. Tada vrijedi $r=|Q O|+|O S|=|T O|+|O S|$ jer $c$ prolazi kroz $T$. Dakle, $O$ pripada elipsi $E\left(T, S, \frac{r}{2}\right)$. Pokažimo i drugu inkluziju, tj. neka je $O \in E\left(T, S, \frac{r}{2}\right)$. Tada je $|O T|+|O S|=r$. Kružnica $k(O,|O T|)$ je kružnica s traženim svojstvom pa $O$ pripada geometrijskom mjestu središta traženih kružnica.

$\mathrm{U}$ slučaju kada je $T \in k$, geometrijsko mjesto središta kružnica $\mathrm{s}$ 


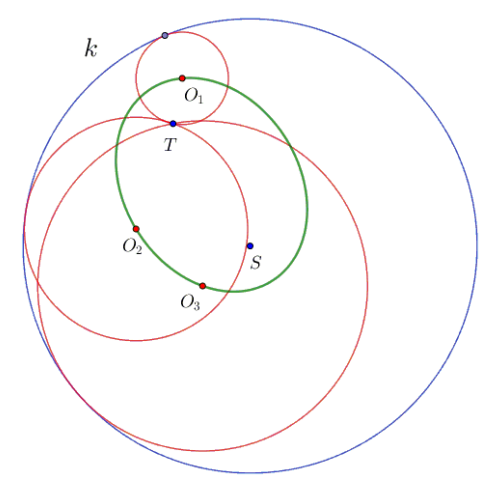

Slika 2

traženim svojstvom je pravac $T S$ bez točke $T$.

3. Konstruiraj kružnicu koja dodiruje dvije zadane kružnice te odredi geometrijsko mjesto središta kružnica sa zadanim svojstvom.

Neka su $k_{1}=k\left(S_{1}, r_{1}\right), k_{2}=k\left(S_{2}, r_{2}\right)$, gdje su $r_{1}, r_{2}$ pozitivni realni brojevi, zadane kružnice, te neka se one ne sijeku i ne leže jedna unutar druge. Neka je $O$ središte kružnice koja dodiruje obje zadane kružnice izvana (iznutra), radijusa $\rho$. Tada vrijedi ||$O S_{1}|-| O S_{2}||=$ ||$\rho+r_{1}|-| \rho+r_{2}||=\left|r_{1}-r_{2}\right|\left(|| O S_{1}|-| O S_{2}||=|| \rho-r_{1}|-| \rho-r_{2}||=\right.$ $\left.\left|-r_{1}+r_{2}\right|=\left|r_{1}-r_{2}\right|\right)$, što povlači da $O$ leži na hiperboli tj. da središta traženih kružnica leže na hiperboli $H\left(S_{1}, S_{2}, \frac{\left|r_{1}-r_{2}\right|}{2}\right)$. Lako se pokaže i druga inkluzija, tj. da je hiperbola $H\left(S_{1}, S_{2}, \frac{\left|r_{1}-r_{2}\right|}{2}\right)$ podskup geometrijskih mjesta središta rješenja (Slika 3).

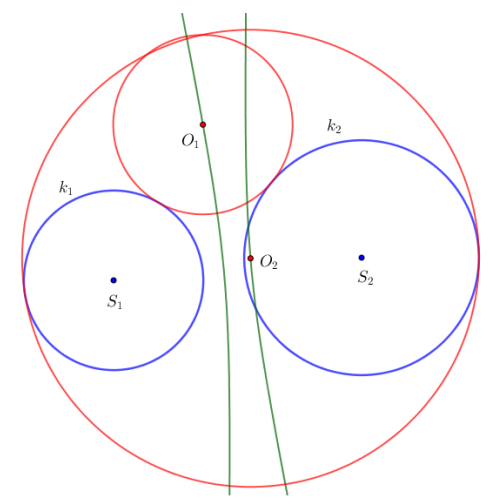

Slika 3 
Neka je $O$ središte kružnice radijusa $\rho$ koja dodiruje jednu zadanu kružnicu izvana a drugu iznutra. Tada vrijedi ||$O S_{1}|-| O S_{2}||=\| \rho-$ $r_{1}|-| \rho+r_{2}||=\left|-r_{1}-r_{2}\right|=r_{1}+r_{2}$ ili ||$O S_{1}|-| O S_{2}||=|| \rho+r_{1}|-| \rho-r_{2}||=$ $r_{1}+r_{2}$, tj. $O \in H\left(S_{1}, S_{2}, \frac{r_{1}+r_{2}}{2}\right)$. Lako se pokaže i druga inkluzija, tj. da je $H\left(S_{1}, S_{2}, \frac{r_{1}+r_{2}}{2}\right)$ podskup geometrijskih mjesta središta rješenja (Slika 4).

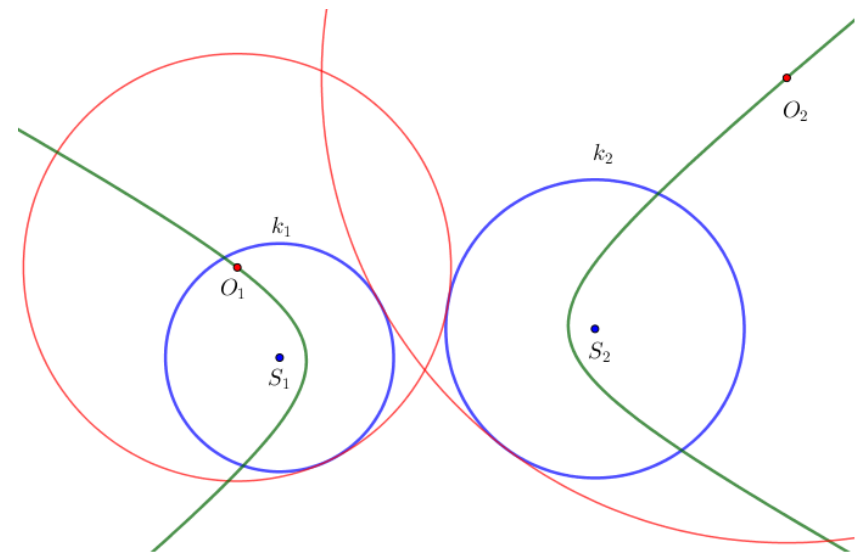

Slika 4

Dakle, u slučaju kada se zadane kružnice ne sijeku, različitih su polumjera i ne leže jedna u drugoj geometrijsko mjesto središta rješenja je unija hiperbola $H\left(S_{1}, S_{2}, \frac{\left|r_{1}-r_{2}\right|}{2}\right) \cup H\left(S_{1}, S_{2}, \frac{r_{1}+r_{2}}{2}\right)$, dočim je $s_{S_{1}{ }^{-} S_{2}} \cup$ $H\left(S_{1}, S_{2}, \frac{r_{1}+r_{2}}{2}\right)$ ako je $r_{1}=r_{2}\left(s \overline{S_{1} S_{2}}\right.$ je simetrala dužine $\left.\overline{S_{1} S_{2}}\right)$.

Kada se jedna od zadanih kružnica nalazi unutar druge zadane kružnice (bez smanjenja općenitosti smijemo pretpostaviti da se $k_{2}$ nalazi unutar $k_{1}$ ) i ne siječe ju, rješenja konstruiramo na analogan način samo što tada nema slučaja da tražena kružnica dodiruje $k_{1}$ i $k_{2}$ obje izvana ili obje iznutra. Središta takvih kružnica nalaze se na elipsi sa žarištima $S_{1}$ i $S_{2}$ i to $E\left(S_{1}, S_{2}, \frac{r_{1}+r_{2}}{2}\right)$, kada tražena kružnica dodiruje izvana $k_{2}$, i $E\left(S_{1}, S_{2}, \frac{\left|r_{2}-r_{1}\right|}{2}\right)$, kada tražena kružnica dodiruje iznutra $k_{2}$, odnosno, za ovaj slučaj GMS rješenja je unija ove dvije elipse (Slika 5).

Slično se analiziraju i ostala rješenja u ovisnosti o položaju i polumjerima zadanih kružnica.

4. Konstruiraj kružnicu koja dodiruje zadani pravac i prolazi zadanom točkom te odredi geometrijsko mjesto središta kružnica sa zadanim svojstvom.

Neka je $p$ zadani pravac i $T$ zadana točka te neka je $T \notin p$. Središte tražene kružnice treba biti jednako udaljeno od $T$ i od $p$, tj. središta leže 


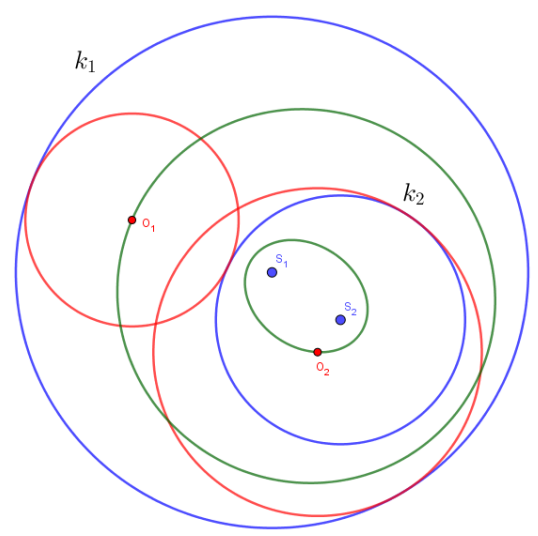

Slika 5

na paraboli $P(T, p)$ (Slika 6). Nadalje, vrijedi i druga inkluzija. Neka je $O$ proizvoljna točka koja leži na paraboli $P(T, p)$. Tada je $k(O,|O T|)$ kružnica s traženim svojstvom.

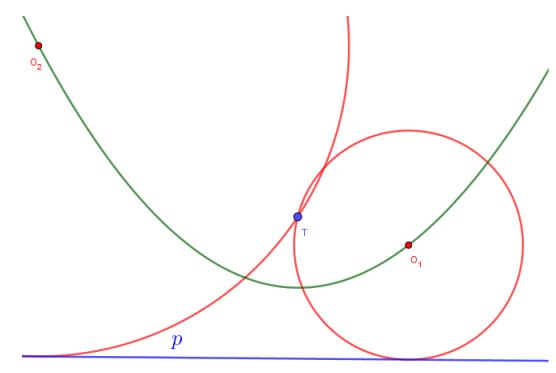

Slika 6

U slučaju kada je $T \in p$, GMS kružnica s traženim svojstvom je $o \backslash\{T\}$, gdje je $o$ okomica na $p$ kroz $T$.

5. Konstruiraj kružnicu koja dodiruje dva zadana pravca te odredi geometrijsko mjesto središta kružnica sa zadanim svojstvom.

Neka su $p_{1}$ i $p_{2}$ zadni pravci te $p_{1} \neq p_{2}$ i $p_{1} \nVdash p_{2}$. Središte traženih kružnica mora biti jednako udaljeno od $p_{1}$ i $p_{2}$, odnosno ono leži na simetrali kutova što ih tvore zadani pravci (bez presječne točke). Vrijedi i druga inkluzija: Neka je $O$ točka koja leži na simetrali kutova što ih tvore zadani pravci, ali bez presječne točke. Tada je $k\left(T, d\left(T, p_{1}\right)\right)$ kružnica s traženim svojstvom. Dakle, GMS rješenja su simetrale kutova što ih zatvaraju zadani pravci bez njihovog presjeka, $p_{1} \cap p_{2}$. 
Ako je $p_{1} \| p_{2}$, GMS kružnica s traženim svojstvom je pravac paralelan s $p_{1}\left(p_{2}\right)$ i od njega udaljen za $\frac{d\left(p_{1}, p_{2}\right)}{2}$.

\section{Konstruiraj kružnicu koja dodiruje zadani pravac i kružnicu} te odredi geometrijsko mjesto središta kružnica sa zadanim svojstvom.

Neka su zadani pravac $p$ i kružnica $k=k(S, r)$ koji se ne sijeku. Tražena kružnica može dodirivati zadanu kružnicu izvana i iznutra. U slučaju kada tražene kružnice dodiruju kružnicu izvana, njihova središta su jednako udaljena od zadane kružnice $k$ i zadanog pravca $p, \mathrm{tj} . d(k, O)=$ $d(p, O)$ za svako središte $O$ rješenja problema. Definirajmo $\rho:=d(p, O)$. Tada je $d(S, O)-r=\rho=d(p, O)$. Ako promatramo pravac $q_{2}$ paralelan sa $p$, udaljen od $p$ za $r$ i sa suprotne strane pravca $p$ od $k$, onda vrijedi $|S O|=r+\rho=d\left(p, q_{2}\right)+d(p, O)=d\left(q_{2}, O\right)$. Dakle, $O$ je točka jednako udaljena od pravca $q_{2}$ i točke $S$, pa ona leži na paraboli $P_{2}=P\left(S, q_{2}\right)$. Lako se pokaže i druga inkluzija, tj. da je parabola čija je ravnalica pravac $q_{2}$ i žarište točka $S$ podskup GMS rješenja.

U slučaju kada tražene kružnice dodiruju kružnicu iznutra njihova središta su za $r$ više udaljene od $S$ nego od $p$, odnosno vrijedi $r+$ $d(S, O)=\rho$, tj. $d(S, O)=\rho-r$. Ako promatramo pravac $q_{1}$ paralelan sa $p$, udaljen od $p$ za $r$ i sa iste strane pravca $p$ kao i $k$, onda vrijedi $d(S, O)=\rho-r=d(p, O)-r=d\left(q_{1}, O\right)$. Dakle, $O$ je točka jednako udaljena od pravca $q_{1}$ i točke $S$ pa ona leži na paraboli $P_{1}=P\left(S, q_{1}\right)$. Lako se pokaže i druga inkluzija, tj. da je parabola $P_{1}$ podskup geometrijskih mjesta središta rješenja. Budući da jedna od tih mogućnosti vrijedi za svako središte tražene kružnice, to je geometrijsko mjesto središta rješenja problema unija tih parabola, odnosno $P_{1} \cup P_{2}$ (Slika 7).

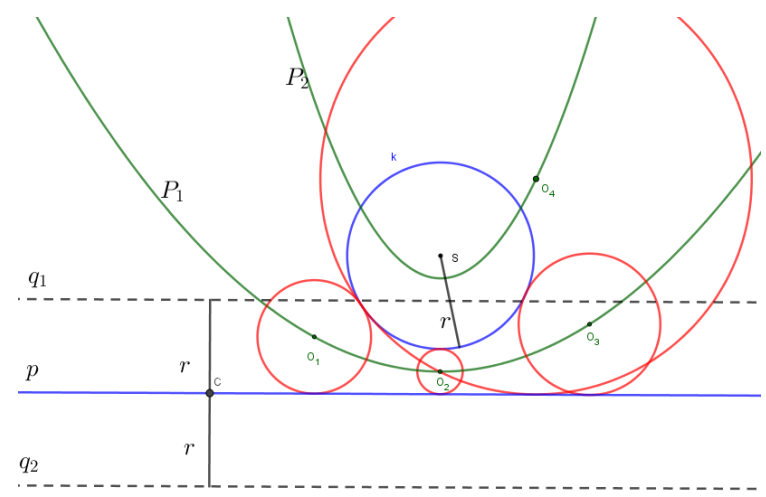


Slično se analiziraju i ostala rješenja u ovisnosti o međusobnom položaju zadane kružnice i zadanog pravca.

\section{Apolonijev problem reda 3}

U ovom odjeljku ćemo razraditi Aplonijev problem reda 3. Ukupno ih ima deset i za svaki od njih je dobro poznato kako, koristeći metode konstruktivne geometrije (prvenstveno inverziju), možemo konstruirati rješenja, odnosno utvrditi postoje li rješenja. No, mi ćemo dokazati da se središta rješenja nalaze u presjeku GMS rješenja tri Apolonijeva problema nižeg reda. Time ćemo pokazati kako tri različita GMS, detaljno razrađena u prethodnomu odjeljku, imaju neprazni presjek. Ovo je zanimljivo jer je riječ o različitim konikama ili pravcima, za koje bismo, na intuitivnoj razini, bez pomnije analize, pomislili da nemaju zajedničkih točaka.

1. Konstruirati kružnicu koja prolazi kroz tri zadane točke.

Neka su zadane 3 različite nekolinearne točke $T_{1}, T_{2}$ i $T_{3}$. Neka su pravci $s_{1}, s_{2}$ i $s_{3}$ GMS kružnica koje prolaze, redom, točkama $T_{1}$ i $T_{2}$, $T_{2}$ i $T_{3}, T_{3}$ i $T_{1}$. Po rješenju 1 . Apolonijevog problema reda 2 , znamo da su ti pravci simetrale dužina određene točkama kroz koje prolaze.

Tvrdnja 1. Vrijedi $s_{1} \cap s_{2} \cap s_{3} \neq \emptyset$ i središte tražene kružnice se nalazi u ovomu presjeku.

Dokaz. Znamo da postoji rješenje, tj. kružnica $k(O, \rho)$ koja prolazi zadanim točkama $T_{1}, T_{2}$ i $T_{3}$. Tada vrijedi $\left|O T_{1}\right|=\left|O T_{2}\right|$. To povlači $O \in s_{1}$. Analogno jednakost $\left|O T_{2}\right|=\left|O T_{3}\right|$ povlači $O \in s_{2}$ i $\left|O T_{1}\right|=\left|O T_{3}\right|$ povlači $O \in s_{3}$. Dakle, $O \in s_{1} \cap s_{2} \cap s_{3}$ i $\rho=\left|O T_{1}\right|$.

Postoji samo jedno rješenje i to je trokutu $\Delta T_{1} T_{2} T_{3}$ opisana kružnica.

Ako su $T_{1}, T_{2}, T_{3}$ kolinearne točke, one ne mogu pripadati istoj kružnici (simetrale dužina su u tom slučaju paralelni pravci pa se ne sijeku).

2. Konstruirati kružnicu koja dodiruje zadani pravac te prolazi dvjema zadanim točkama.

Neka su $T_{1}$ i $T_{2}, T_{1} \neq T_{2}$, zadane točke te $p$ zadani pravac. Ovisno o međusobnom položaju zadanih objekata razlikujemo više slučajeva:

$1^{\circ}$ Neka $p$ ne prolazi točkama $T_{1}$ i $T_{2}, T_{1} \neq T_{2}$ i neka se one nalaze s iste strane pravca $p$ ( $\mathrm{u}$ istoj poluravnini određenoj sa $p$ ). Iz rješenja Apolonijevih problema reda 2 znamo da je GMS kružnica koje prolaze kroz $T_{1}$ i dodiruju pravac $p$ prarabola $P_{1}=P\left(T_{1}, p\right)$, GMS kružnica koje prolaze kroz $T_{2}$ i dodiruju pravac $p$ parabola $P_{2}=P\left(T_{2}, p\right)$ i GMS kružnica koje prolaze točkama $T_{1}$ i $T_{2}$ simetrala $s$ dužine $\overline{T_{1} T_{2}}$. 
Tvrdnja 2. Vrijedi $P_{1} \cap P_{2} \cap s \neq \emptyset$ i središte tražene kružnice se nalazi u ovomu presjeku (Slika 8).

Dokaz. Znamo da postoji rješenje (4]), tj. kružnica $k(O, \rho)$ koja dodiruje pravac $p$ i prolazi točkom $T_{1}$, tj. vrijedi $d\left(O, T_{1}\right)=d(O, p)$, što povlači $O \in P_{1}$. Analogno se pokaže i $O \in P_{2}$. Budući da kružnica prolazi točkama $T_{1}$ i $T_{2}$, to je $O$ jednako udaljen od obiju točaka, odnosno $d\left(T_{1}, O\right)=d\left(T_{2}, O\right)$ pa je $O \in s$. Dakle, $O \in P_{1} \cap P_{2} \cap s$ i $\rho=\left|O T_{1}\right|$.

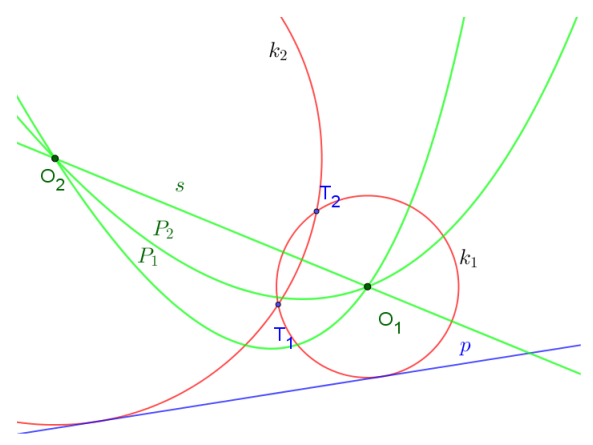

Slika 8

Uočimo da ne moraju biti dva rješenja, nego može biti i jedno i to $u$ slučaju kada je $T_{1} T_{2} \| p$ (simetrala dužine $s$ je okomita na $p$ i može sjeći parabole u samo jednoj točki).

$2^{\circ}$ U slučaju kada vrijedi $T_{1}, T_{2} \in p$ i $T_{1} \neq T_{2}$ rješenja nema. GMS kružnica koje dodiruju $p$ i prolaze kroz $T_{1}\left(T_{2}\right)$ su pravci $q_{1}\left(q_{2}\right)$, okomice na $p$ kroz $T_{1}\left(T_{2}\right)$. Tada su $q_{1}, q_{2}$ i $s$ različiti paralelni pravci (okomice na isti pravac $p$ ) pa nemaju presjek.

$3^{\circ}$ Neka je $T_{1} \in p\left(T_{2} \in p\right)$. Tada postoji jedno rješenje.

$4^{\circ}$ Neka se $T_{1}$ i $T_{2}$ nalaze s različitih strana pravca $p$. Budući da se i u ovomu slučaju središte rješenja mora nalaziti u $P_{1} \cap P_{2} \cap s$, a parabole $P_{1}$ i $P_{2}$ se očito ne sijeku, to rješenje ne postoji.

\section{Konstruirati kružnicu koja prolazi dvjema zadanim to- čkama te dodiruje zadanu kružnicu. \\ Neka su zadane točke $T_{1}$ i $T_{2}, T_{1} \neq T_{2}$, i kružnica $k=k(S, r)$. Broj rješenja ovisi o međusobnom položaju zadanih objekata.}


$1^{\circ}$ Neka su $T_{1}$ i $T_{2}$ izvan kružnice $k$. Tada je hiperbola $H_{1}=$ $H\left(T_{1}, S, \frac{r}{2}\right)$ GMS kružnica koje dodiruju $k$ i prolaze kroz $T_{1}$, hiperbola $H_{2}=H\left(T_{2}, S, \frac{r}{2}\right)$ GMS kružnica koje dodiruju $k$ i prolaze kroz $T_{2}$ te pravac $s$ GMS kružnica koje prolaze točkama $T_{1}$ i $T_{2}$ (Apolonijevi problemi reda 2).

Tvrdnja 3. Vrijedi $H_{1} \cap H_{2} \cap s \neq \emptyset i$ središte tražene kružnice se nalazi u ovomu presjeku (Slika 9).

Dokaz. Znamo da postoji kružnica $c=k(O, \rho)$ s traženim svojstvom (4). Tada $c$ prolazi kroz $T_{1}$ i dodiruje $k$. Budući da $c$ može $k$ dodirivati izvana i iznutra, to slijedi $d\left(O, T_{1}\right)=d(O, S)-r$ ili $d\left(O, T_{1}\right)=d(O, S)+r$. Slijedi $\left|d\left(O, T_{1}\right)-d(O, S)\right|=r$ pa vrijedi $O \in H_{1}$. Analogno se pokaže $O \in H_{2}$. Nadalje, kružnica $c$ prolazi kroz $T_{1}$ i $T_{2}$ pa vrijedi $d\left(T_{1}, O\right)=$ $d\left(T_{2}, O\right)$, što povlači $O \in s$. Dakle, $O \in H_{1} \cap H_{2} \cap s$ i $\rho=\left|T_{1} O\right|$.

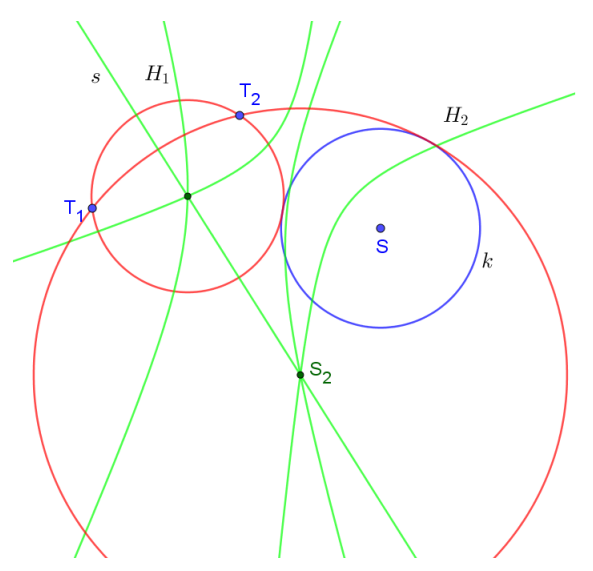

Slika 9

U ovomu slučaju postoje dva rješenja i to kada se sijeku grane hiperbola na kojima leže GMS kružnica koje dodiruju kružnicu izvana i kada se sijeku grane hiperbola na kojima leže GMS kružnica koje dodiruju kružnicu iznutra.

$2^{\circ}$ Neka je $T_{1}$ unutar, a $T_{2}$ izvan kružnice $k$. Tada nema rješenja. Slično kao i pod $1^{\circ}$ se pokaže da ako rješenje postoji, središte te kružnice se nalazi u presjeku $H_{2} \cap E \cap s$, gdje je $E=E\left(T_{1}, S, \frac{r}{2}\right)$ elipsa (GMS kružnica koje prolaze kroz $T_{1}$ i dodiruju $k$ ). No, pretpostavimo li da postoji $O \in H_{2} \cap E \cap s$ onda vrijedi ||$T_{1} O|+| S O||=r=|| T_{2} O \mid-$ $|S O||,| T_{1} O|=| T_{2} O \mid$. Slijedi $\left|T_{1} O\right|+|S O|=\left|T_{1} O\right|-|S O|$ ili $\left|T_{1} O\right|+$ 
$|S O|=-\left|T_{1} O\right|+|S O|$. Odnosno $S=O$ ili $T_{2}=O$, što nas dovodi do kontradikcije.

$3^{\circ}$ Neka se obje točke nalaze na kružnici $k$. Tada je tražena kružnica zadana kružnica $k$. Naime, GMS kružnica koje dodiruju $k$ i prolaze kroz $T_{1}\left(T_{2}\right)$ je $T_{1} S \backslash\left\{T_{1}\right\}\left(T_{2} S \backslash\left\{T_{2}\right\}\right)$, a GMS kružnica koje prolaze točkama $T_{1}$ i $T_{2}$ je simetrala dužine $\overline{T_{1} T_{2}}$. Budući da simetrala tetive kružnice prolazi njezinim središtem, to je presjek ta tri GMS točka $S$, a radijus tražene kružnice je $\left|S T_{1}\right|$.

$4^{\circ}$ Neka se točke $T_{1}$ i $T_{2}$ nalaze unutar kružnice $k$. Analognim razmatranjem kao i pod $1^{\circ}$ se pokaže da postoje 2 rješenja središta kojih se nalaze u presjeku odgovarajućih GMS rješenja Aplolonijevih problema reda 2: elipse $E_{1}=E\left(T_{1}, S, \frac{r}{2}\right), E_{2}=E\left(T_{2}, S, \frac{r}{2}\right)$ i simetrale $s$ (Slika 10).

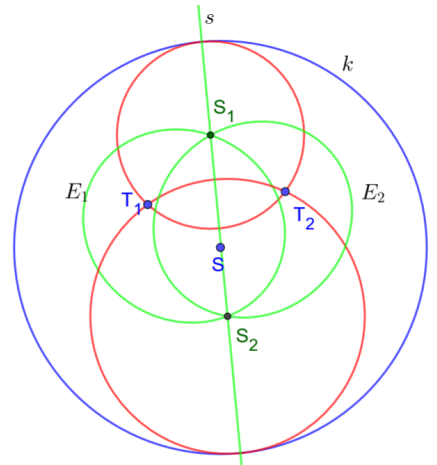

Slika 10

$5^{\circ}$ Neka se jedna od točaka nalazi na $k$, a druga ne leži na $k$. Analognim razmatranjem kao i pod $1^{\circ}$ se pokaže da postoji 1 rješenje.

\section{Konstruirati kružnicu koja prolazi zadanom točkom te dodiruje dva zadana pravca.}

Neka je zadana točka $T$ i pravci $p_{1}$ i $p_{2}$. Ovisno o međusobnom položaju pravaca i točke razlikujemo više slučajeva:

$1^{\circ}$ Neka je $p_{1} \nVdash p_{2}$ i $T$ ne pripada pravcima $p_{1}$ i $p_{2}$. Označimo sa $Q$ presjek pravca $p_{1}$ i $p_{2}$ i sa $s_{1}, s_{2}$ simetrale kutova što ih zatvaraju $p_{1}$ i $p_{2}$. Tada je $\left(s_{1} \cup s_{2}\right) \backslash\{Q\}$ GMS kružnica koje dodiruju $p_{1}$ i $p_{2}$, parabola $P_{1}=P\left(T, p_{1}\right)$ GMS kružnica koje dodiruju $p_{1}$ i prolaze kroz $T$ i parabola $P_{2}=P\left(T, p_{2}\right)$ GMS kružnica koje dodiruju pravac $p_{2}$ i prolaze točkom $T$. 
Tvrdnja 4. Vrijedi $\left(\left(s_{1} \cup s_{2}\right) \backslash\{Q\}\right) \cap P_{1} \cap P_{2} \neq \emptyset$ i središte tražene kružnice se nalazi u tomu presjeku (Slika 11).

Dokaz. Znamo da postoji kružnica $c=k(O, \rho)$ s traženim svojstvom (4]). Budući da $c$ dodiruje $p_{1}$ i $p_{2}$, to povlači $d\left(O, p_{1}\right)=d\left(O, p_{2}\right)$ pa je $O \in\left(s_{1} \cup s_{2}\right)$. Budući da je $r>0$, to slijedi $O \neq Q$. Nadalje, $c$ dodiruje pravac $p_{1}$ i prolazi točkom $T$ pa vrijedi $d(O, T)=d\left(O, p_{1}\right)$, što povlači $O \in P_{1}$. Analogno se pokaže da vrijedi i $O \in P_{2}$. Dakle, $\left.O \in\left(\left(s_{1} \cup s_{2}\right) \backslash\{Q\}\right) \cap P_{1} \cap P_{2}, \rho=|O T|\right)$.

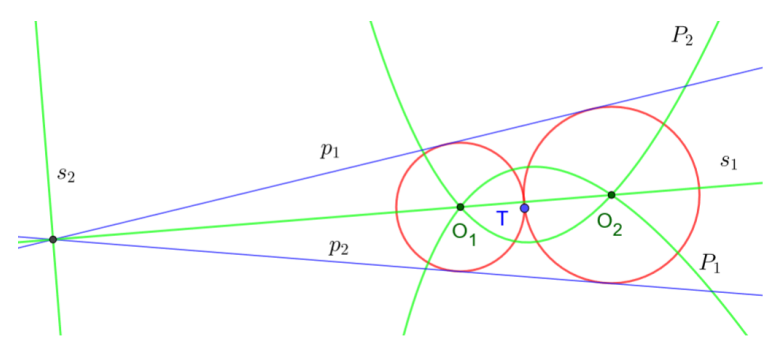

Slika 11

U ovomu slučaju postoje dva rješenja ([1]).

$2^{\circ}$ Neka je $p_{1} \| p_{2}$ i $T$ ne pripada pravcima $p_{1}$ i $p_{2}$ te se nalazi između njih. Analognim razmatranjem kao pod $1^{\circ}$ se pokaže da postoje dva rješenja čija središta se nalaze u presjeku odgovarajućih GMS rješenja Apolonijeva problema reda 2 (pravac i dvije parabole).

$3^{\circ}$ Neka vrijedi $p_{1} \perp p_{2}$ i $T$ pripada jednom zadanom pravcu, a ne pripada drugomu. Tada postoje dva rješenja.

$4^{\circ}$ Neka je $p_{1} \nVdash p_{2}$ i $\{T\}=p_{1} \cap p_{2}$. Tada se središte rješenja mora nalaziti u presjeku GMS rješenja odgovarajućih Apolonijevih problema reda 2: $\left(s_{1} \cup s_{2}\right) \backslash\{T\}, o_{1} \backslash\{T\}$ i $o_{2} \backslash\{T\}$ (gdje su $o_{1}$ i $o_{2}$ okomice u $T$ na $p_{1}$ i $p_{2}$, redom). No, njihov presjek je prazan skup, pa u ovom slučaju nema rješenja.

$5^{\circ}$ Neka je $p_{1} \| p_{2}$, a $T$ se ne nalazi između pravaca $p_{1}$ i $p_{2}$, te ne leži ni na jednom od njih. Tada se središte rješenja mora nalaziti u presjeku GMS rješenja odgovarajućih Apolonijevih problema reda 2. No, budući da se parabola koja je GMS kružnica koje dodiruju zadani pravac koji je bliže točki $T$ i pravac koji je GMS kružnica koje dodiruju zadane pravce ne sijeku, to rješenje za ovaj slučaj ne postoji. 
$6^{\circ}$ Neka je $p_{1} \| p_{2}$ i $T \in p_{1}\left(p_{2}\right)$. Tada postoji jedinstveno rješenje čije središte se nalazi u presjeku dva međusobno okomita pravca i parabole.

\section{Konstruirati kružnicu koja prolazi zadanom točkom, do- diruje zadani pravac i kružnicu.}

Neka su zadani točka $T$, pravac $p$ i kružnica $k=k(S, r)$, gdje je $r>0$. Postoji više slučajeva ovisno o međusobnom položaju zadanih elemenata:

$1^{\circ}$ Neka je $k \cap p=\emptyset, T \notin p, T$ leži izvan kružnice $k$, te naka su $T$ i $k$ s iste strane pravca $p$. Tada je hiperbola $H=H\left(S, T, \frac{r}{2}\right)$ GMS kružnica koje dodiruju $k$ i prolaze točkom $T$, parabola $P_{1}=P(T, p)$ GMS kružnica koje dodiruju $p$ i prolaze kroz $T$ i $P_{2} \cup P_{3}$ GMS kružnica koje dodiruju $p$ i $k$, gdje je parabola $P_{2}\left(P_{3}\right)$ GMS kružnica koje dodiruju kružnicu $k$ izvana (iznutra).

Tvrdnja 5. Vrijedi $H \cap P_{1} \cap\left(P_{2} \cup P_{3}\right) \neq \emptyset i$ središte tražene kružnice se nalazi u tomu presjeku (Slika 12).

Dokaz. Znamo da postoji kružnica $c=k(O, \rho)$ s traženim svojstvom (4). Tada $c$ prolazi kroz $T$ i dodiruje $k$. Budući da $c$ može dodirivati $k$ izvana i iznutra, to slijedi $d(O, T)=d(O, S)-r$ ili $d(O, T)=d(O, S)+r$. Slijedi $|d(O, A)-d(O, S)|=r$ pa je $O \in H$. Nadalje, $c$ dodiruje $p$ i prolazi kroz $T$, iz čega slijedi da je $d(O, T)=d(O, p)$. To povlači $O \in P_{1}$. Također $c$ dodiruje $p$ i $k$ i može $k$ dodirivati izvana ili iznutra, tj. vrijedi $d(O, p)=d(O, k)$, odnosno $d(O, S)=d(O, p)+r$, ili $d(O, S)=d(O, p)-r$ iz čega slijedi da je $O \in P_{2} \cup P_{3}$. Dakle, $O \in H \cap P_{1} \cap\left(P_{2} \cup P_{3}\right)$ i $\rho=d(O, T)$.

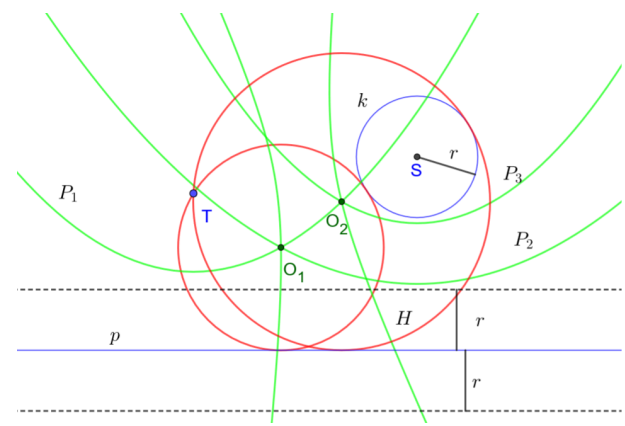

Slika 12 
Primijetimo da u ovomu slučaju postoje najviše 4 rješenja ([1]).

$2^{\circ}$ Ako su $k \cap p=\emptyset, T$ i $k$ sa različite strane pravca $p$, onda rješenja nema. Naime parabole $P_{1}, P_{2}$ i $P_{3}$ se u ovomu slučaju ne sijeku.

$3^{\circ}$ Ako je $k \cap p \neq \emptyset, p$ tangenta od $k$ i $T$ ne leži na $p$ i nalazi se unutar kružnice $k$, onda postoji jedinstveno rješenje. Središte kružnice je presjek okomice u diralištu $D p$ na $k$ i simetralom dužine $\overline{D T}$.

$4^{\circ}$ Ako je $k \cap p \neq \emptyset, p$ tangenta od $k$ i $T \in p, k$, onda postoji beskonačno mnogo rješenja: Središta traženih kružnica leže na okomici iz $T$ na $p$, ali bez točke $T$ (Slika 13).

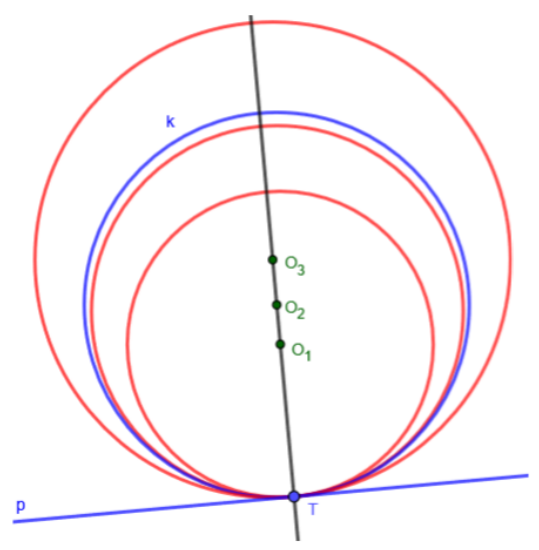

Slika 13

Svi ostali slučajevi se analogno analiziraju.

\section{Konstruiraj kružnicu koja prolazi zadanom točkom, te dodiruje dvije zadane kružnice.}

Neka su zadane točka $T$ te kružnice $k_{1}=k\left(S_{1}, r_{1}\right)$ i $k_{2}=k\left(S_{2}, r_{2}\right)$, $r_{1}, r_{2}>0$. Promotrimo različite međusobne položaje zadanih objekata i pripadajući broj rješenja:

$1^{\circ}$ Neka se točka $T$ nalazi izvan zadanih kružnica i neka se one nalaze jedna izvan druge. Tada je hiperbola $H_{1}=H\left(T, S_{1}, \frac{r_{1}}{2}\right)$ GMS kružnica koje dodiruju $k_{1}$ i prolaze točkom $T$, hiperbola $H_{2}=H\left(T, S_{2}, \frac{r_{2}}{2}\right)$ GMS kružnica koje dodiruju $k_{2}$ i prolaze točkom $T$. Neka je $H_{3} \cup H_{4}$ GMS kružica koje dodiruju zadane kružnice (3. Apolonijev problem reda 2), gdje je hiperbola $H_{3}\left(H_{4}\right)$ GMS kružnica koje dodiruju zadane kružnice izvana ili iznutra (jednu od kružnica izvana, a drugu iznutra). 
Tvrdnja 6. Vrijedi $H_{1} \cap H_{2} \cap\left(H_{3} \cup H_{4}\right) \neq \emptyset$ i središte tražene kružnice se nalazi u tomu presjeku (Slika 14).

Dokaz. Znamo da postoji kružnica $c=k(O, \rho)$ s traženim svojstvom (4]). Tada $c$ prolazi kroz $T$ i dodiruje $k_{1}$. Budući da $c$ može $k_{1}$ dodirivati izvana i iznutra, to slijedi $d(O, T)=d\left(O, S_{1}\right)-r_{1}$ ili $d(O, T)=d\left(O, S_{1}\right)+$ $r_{1}$. Slijedi $\left|d(O, T)-d\left(O, S_{1}\right)\right|=r_{1}$, tj. $O \in H_{1}$. Analogno se pokaže da vrijedi $O \in H_{2}$. Nadalje, $c$ dodiruje $k_{1}$ i $k_{2}$. Može obje kružnice dodirivati izvana ili iznutra, jednu dodirivati iznutra, a drugu izvana. Ako $c$ dodiruje $k_{1}$ i $k_{2}$ izvana(iznutra), onda vrijedi ||$O S_{1}|-| O S_{2}||=|| \rho+r_{1}|-| \rho+$ $r_{2}||=\left|r_{1}-r_{2}\right|\left(|| O S_{1}|-| O S_{2}||=|| \rho-r_{1}|-| \rho-r_{2}||=\left|-r_{1}+r_{2}\right|=\left|r_{1}-r_{2}\right|\right)$ iz čega slijedi $O \in H_{3}$. Ako $c$ dodiruje $k_{1}$ izvana (iznutra), a $k_{2}$ iznutra (izvana), onda vrijedi ||$O S_{1}|-| O S_{2}||=|| \rho+r_{1}|-| \rho-r_{2}||=r_{1}+r_{2}$ $\left(|| O S_{1}|-| O S_{2}||=|| \rho-r_{1}|-| \rho+r_{2}||=r_{1}+r_{2}\right)$. Slijedi $O \in H_{4}$. Dakle, $O \in H_{1} \cap H_{2} \cap\left(H_{3} \cup H_{4}\right)$ i $\rho=|O T|$.

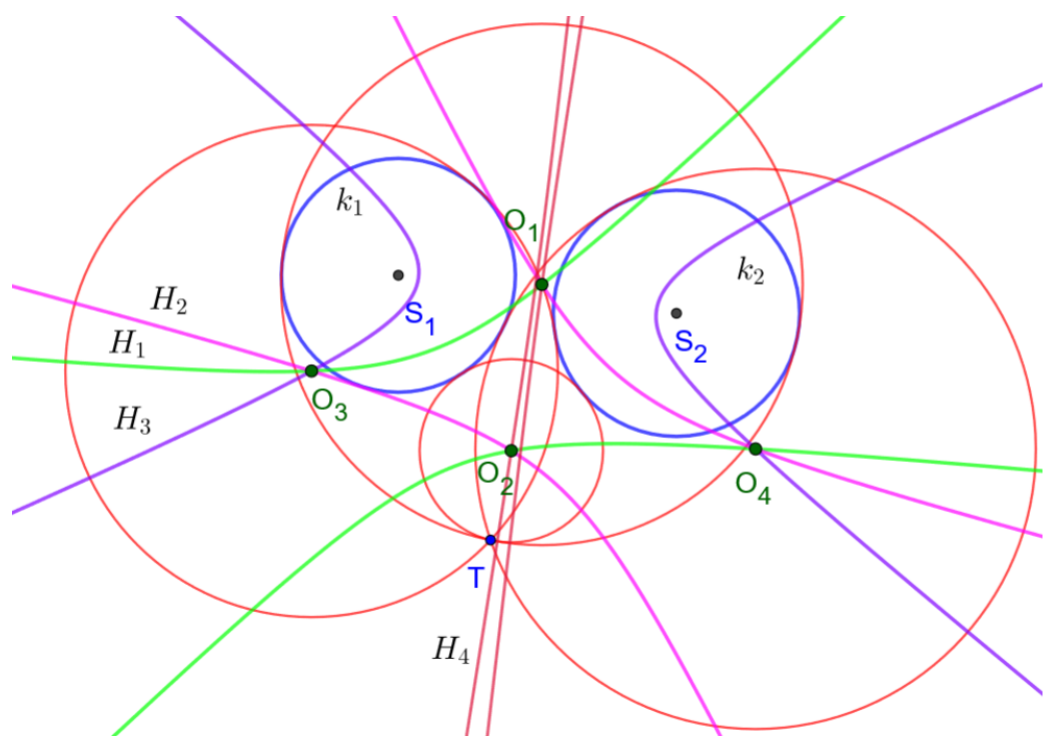

Slika 14

Slike hiperbole $H_{1}, H_{2}, H_{3}$ i $H_{4}$ zbog preglednosti su obojane različitim bojama.

Primijetimo da u ovom slučaju imamo 4 rješenja ([1]).

Svi ostali slučajevi se analogno analiziraju, a broj rješenja može biti $0,1,2,3,4$ ili beskonačan (kada je $k_{1} \cap k_{2}=\{T\}$ ). 


\section{Konstruirati kružnicu koja dodiruje tri zadana pravca.}

Neka su $p_{1}, p_{2}$ i $p_{3}$ zadani pravci. Promotrimo različite međusobne položaje zadanih pravaca:

$1^{\circ}$ Neka zadani pravci $p_{1}, p_{2}, p_{3}$ nisu međusobno paralelni. Neka je $\{A\}=p_{1} \cap p_{2},\{B\}=p_{2} \cap p_{3}$ i $\{C\}=p_{3} \cap p_{1}$. Tada su $\left(s_{1} \cup s_{2}\right) \backslash\{A\}$, $\left(s_{3} \cup s_{4}\right) \backslash\{B\},\left(s_{5} \cup s_{6}\right) \backslash\{C\}$, gdje su $s_{1}$ i $s_{2}$ simetrale kutova što ih zatvaraju $p_{1}$ i $p_{2}, s_{3}$ i $s_{4}$ simetrale kutova što ih zatvaraju $p_{2}$ i $p_{3}, s_{5}$ i $s_{6}$ simetrale kutova što ih zatvaraju $p_{1}$ i $p_{3}$, GMS kružnica koje dodiruju pravce $p_{1}$ i $p_{2}, p_{2}$ i $p_{3}, p_{1}$ i $p_{3}$, redom.

Tvrdnja 7. Vrijedi $\left(\left(s_{1} \cup s_{2}\right) \backslash\{A\}\right) \cap\left(\left(s_{3} \cup s_{4}\right) \backslash\{B\}\right) \cap\left(\left(s_{5} \cup s_{6}\right) \backslash\{C\}\right) \neq \emptyset$ $i$ središte tražene kružnice se nalazi u tomu presjeku (Slika 15).

Dokaz. Rješenja ovoga problema su trokutu $\triangle A B C 3$ pripisane i 1 upisana kružnica čija središta se nalaze u promatranomu presjeku.

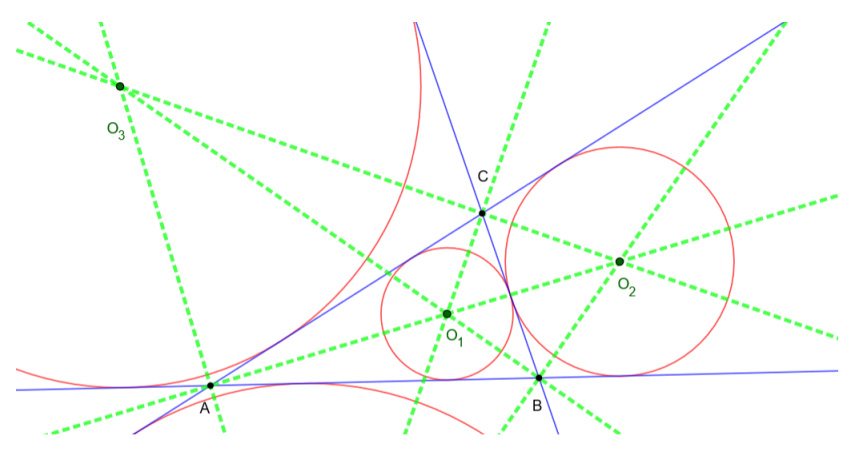

Slika 15

$2^{\circ}$ Ako vrijedi $p_{1} \| p_{2}$ i $p_{2} \nVdash p_{3}$, onda postoje dva rješenja zadanog problema. Središta traženih kružnica konstruiramo kao sjecišta simetrala kutova što ih zatvaraju pravci $p_{1}$ i $p_{3}$ te $p_{2}$ i $p_{3}$.

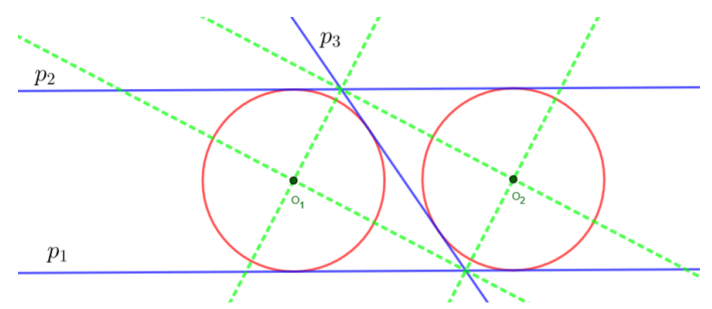

Slika 16 
$3^{\circ}$ Neka vrijedi $p_{1}\left\|p_{2}\right\| p_{3}$ i $p_{1} \neq p_{2} \neq p_{3}$. Tada su GMS kružnica koje dodiruju pravce $p_{1}$ i $p_{2}, p_{2}$ i $p_{3}, p_{3}$ i $p_{1}$ međusobno različiti paralelni pravci, a njihov presjek je prazan pa rješenja nema.

\section{Konstruirati kružnicu koja dodiruje dvije zadane kružnice} i zadani pravac.

Neka su zadane kružnice $k_{1}=k\left(S_{1}, r_{1}\right)$ i $k_{2}=k\left(S_{2}, r_{2}\right), r_{1}, r_{2}>0$, te pravac $p$. Promotrimo različite međusobne položaje zadanih objekata:

$1^{\circ}$ Neka se $k_{1}, k_{2}$ i $p$ međusobno ne sijeku te neka se kružnice nalaze jedna izvan druge, s iste strane pravca $p$. Tada su $P_{1} \cup P_{2}$ i $P_{3} \cup P_{4}$ GMS kružnica koje dodiruju kružnicu $k_{1}$ i pravac $p, k_{2}$ i $p$, redom gdje je parabola $P_{1}\left(P_{3}\right)$ GMS kružnica koje dodiruju $k_{1}\left(k_{2}\right)$ izvana a parabola $P_{2}$ $\left(P_{4}\right)$ GMS kružnica koje dodiruju $k_{1}\left(k_{2}\right)$ iznutra. Nadalje je $H_{1} \cup H_{2}$, GMS kružnica koje dodiruju $k_{1}$ i $k_{2}$, gdje je hiperbola $H_{1}$ GMS kružnica koje dodiruju $k_{1}$ i $k_{2}$ izvana ili iznutra, a hiperbola $H_{2}$ GMS kružnica koje dodiruju jednu od zadanih kružnica izvana, a drugu iznutra.

Tvrdnja 8. Vrijedi $\left(P_{1} \cup P_{2}\right) \cap\left(P_{3} \cup P_{4}\right) \cap\left(H_{1} \cup H_{2}\right) \neq \emptyset i$ središte tražene kružnice se nalazi u tomu presjeku (Slika 17).

Dokaz. Znamo da postoji kružnica $c=k(O, \rho)$ s traženim svojstvom (4]). Tada $c$ dodiruje $k_{1}$ i $k_{2}$. Može obje kružnice dodirivati izvana ili iznutra, jednu dodirivati iznutra, a drugu izvana. Ako $c$ dodiruje $k_{1}$ i $k_{2}$ izvana (iznutra), onda vrijedi ||$O S_{1}|-| O S_{2}||=|| \rho+r_{1}|-| \rho+r_{2}||=\left|r_{1}-r_{2}\right|$ $\left(|| O S_{1}|-| O S_{2}||=|| \rho-r_{1}|-| \rho-r_{2}||=\left|-r_{1}+r_{2}\right|=\left|r_{1}-r_{2}\right|\right)$, iz

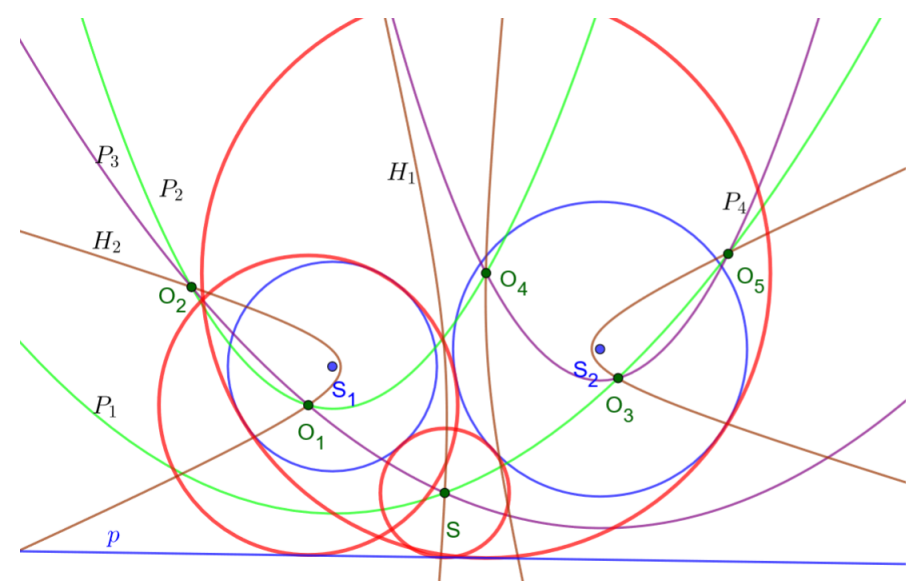

Slika 17 
čega slijedi $O \in H_{1}$. Ako $c$ dodiruje $k_{1}$ izvana (iznutra), a $k_{2}$ iznutra (izvana), onda vrijedi ||$O S_{1}|-| O S_{2}||=|| \rho+r_{1}|-| \rho-r_{2}||=r_{1}+r_{2}$ $\left(|| O S_{1}|-| O S_{2}||=|| \rho-r_{1}|-| \rho+r_{2}||=r_{1}+r_{2}\right)$ pa slijedi $O \in H_{2}$. Dakle, $O \in H_{1} \cup H_{2}$. Nadalje, $c$ dodiruje $p$ i $k_{1}$ pri čemu $k_{1}$ može dodirivati izvana ili iznutra, tj. vrijedi $d(O, p)=d\left(O, k_{1}\right)$, odnosno $d\left(O, S_{1}\right)=$ $d(O, p)+r_{1}$, ili $d(O, p)=d\left(O, S_{1}\right)+r_{1}$, odnosno $d\left(O, S_{1}\right)=d(O, p)-r_{1}$. To povlači $O \in P_{1} \cup P_{2}$. Analogno se pokaže da vrijedi $O \in P_{3} \cup P_{4}$. Dakle, $O \in\left(P_{1} \cup P_{2}\right) \cap\left(P_{3} \cup P_{4}\right) \cap\left(H_{1} \cup H_{2}\right)$ i $\rho=d(S, p)$.

U ovomu slučaju imamo 8 rješenja ([1]).

Zbog preglednosti na Slici 17 GMS kružnica za pojedine Apolonijeve probleme reda 2 su obojana različitim bojama i nisu istaknute sve tražene kružnice već samo njih tri iako ima više vidljivih središta traženih kružnica.

$2^{\circ}$ U slučaju kada se kružnice $k_{1}$ i $k_{2}$ sijeku ili kada se jedna nalazi unutar druge, a pravac $p$ siječe veću tada provodimo analizu analognu onoj iz slučaja $1^{\circ}$ samo što se broj rješenja razlikuje ovisno o dodatnim međusobnim odnosima zadanih objekata.

$3^{\circ}$ Ako su zadane kužnice jedna unutar druge, a zadani pravac ih ne siječe, onda rješenja očito nema.

Svi ostali slučajevi se analogno analiziraju.

\section{Konstruirati kružnicu koja dodiruje dva zadana pravca i zadanu kružnicu.}

Neka su zadani pravci $p_{1}$ i $p_{2}$ te kružnica $k=k(S, r)$, gdje je $r$ proizvoljan pozitivan realan broj.

$1^{\circ}$ Neka se zadani pravci sijeku i neka ne sijeku zadanu kružnicu. Označimo sa $Q$ njihov presjek i sa $s_{1}, s_{2}$ simetrale kutova što ih zatvaraju $p_{1}$ i $p_{2}$. Tada je $\left(s_{1} \cup s_{2}\right) \backslash\{Q\}$ GMS kružnica koje dodiruju $p_{1}$ i $p_{2}$. Neka je $P_{1} \cup P_{2}$ GMS kružnica koje dodiruju $p_{1}$ i $k$, gdje je parabola $P_{1}$ $\left(P_{2}\right)$ GMS kružnica koje $k$ dodiruju izvana (iznutra) i neka je $P_{3} \cup P_{4}$ GMS kružnica koje dodiruju pravac $p_{2}$ i $k$, gdje je parabola $P_{3}\left(P_{4}\right)$ GMS kružnica koje $k$ dodiruju izvana (iznutra).

Tvrdnja 9. Vrijedi $\left(\left(s_{1} \cup s_{2}\right) \backslash\{Q\}\right) \cap\left(P_{1} \cup P_{2}\right) \cap\left(P_{3} \cup P_{4}\right) \neq \emptyset i$ središte tražene kružnice se nalazi u tomu presjeku (Slika 18).

Dokaz. Znamo da postoji kružnica $c=k(O, \rho)$ s traženim svojstvom (4]). Tada $c$ dodiruje $p_{1}$ i $p_{2}$. Slijedi $d\left(O, p_{1}\right)=d\left(O, p_{2}\right)$ pa je $O \in$ $\left(s_{1} \cup s_{2}\right) \backslash\{Q\}$. Nadalje, $c$ dodiruje $p_{1}$ i $k$, pri čemu $k$ dodiruje izvana 
ili iznutra iz čega slijedi da je $d\left(O, p_{1}\right)=d(O, k)$, odnosno $d(O, S)=$ $d\left(O, p_{1}\right)+r$, ili $d\left(O, p_{1}\right)=d(O, S)+r, \mathrm{tj} . d(O, S)=d\left(O, p_{1}\right)-r$. Slijedi $O \in P_{1} \cup P_{2}$. Analogno se pokaže da vrijedi $O \in P_{3} \cup P_{4}$. Dakle, $O \in\left(P_{1} \cup P_{2}\right) \cap\left(P_{3} \cup P_{4}\right) \cap\left(\left(s_{1} \cup s_{2}\right) \backslash\{Q\}\right)$ i $\rho=d\left(O, p_{1}\right)$.

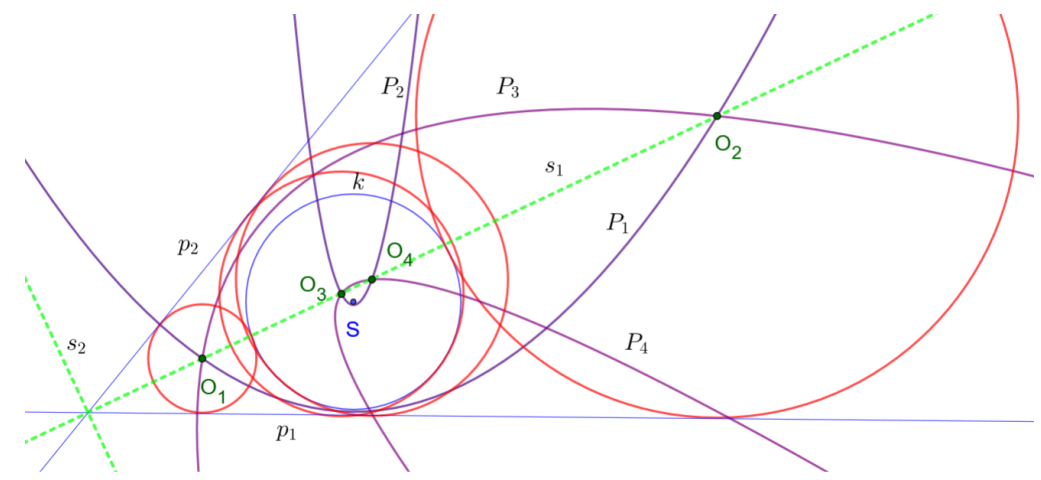

Slika 18

U ovomu slučaju postoji 8 rješenja.

$2^{\circ}$ Ako su pravci paralelni, onda postoje četiri rješenja. Konstrukcija je analogna prethodno opisanoj, ali neki slučajevi propadaju.

Svi ostali slučajevi se analogno analiziraju.

10. Konstruiraj kružnicu koja dodiruje tri zadane kružnice.

Neka su zadane kružnice $k_{1}=k\left(S_{1}, r_{1}\right), k_{2}=\left(k S_{2}, r_{2}\right)$ i $k_{3}=$ $k\left(S_{3}, r_{3}\right), r_{1}, r_{2}, r_{3}>0$. Promotrit ćemo, zbog jednostavnosti, samo slučaj kada niti jedna od kružnica nije sadržana ni u jednoj od preostalih dviju te kada se nikoje dvije ne sijeku. Tada je $H_{1} \cup H_{2}$, gdje je hiperbola $H_{1}$ GMS kružnica koje dodiruju $k_{1}$ i $k_{2}$ izvana ili iznutra, a hiperbola $H_{2}$ GMS kružnica koje jednu od $k_{1}$ i $k_{2}$ dodiruju izvana, a drugu iznutra, rješenje 3. Apolonijeva problema reda 2, tj. GMS kružnica koje dodiruju $k_{1}$ i $k_{2}$. Analogno značenje imaju $H_{3} \cup H_{4}$ (GMS kružnica koje dodiruju $k_{2}$ i $\left.k_{3}\right)$ te $H_{5} \cup H_{6}$ (GMS kružnica koje dodiruju $k_{1}$ i $k_{3}$ ).

Tvrdnja 10. Vrijedi $\left(H_{1} \cup H_{2}\right) \cap\left(H_{3} \cup H_{4}\right) \cap\left(H_{5} \cup H_{6}\right) \neq \emptyset i$ središte tražene kružnice se nalazi u tomu presjeku.

Dokaz. Neka je $c=k(O, \rho)$ kružnica s traženim svojstvom. Tada $c$ dodiruje $k_{1}$ i $k_{2}$ i može obje kružnice dodirivati izvana ili iznutra, jednu dodirivati iznutra, a drugu izvana. Ako $c$ dodiruje $k_{1}$ i $k_{2}$ izvana (iznutra), onda vrijedi ||$O S_{1}|-| O S_{2}||=|| \rho+r_{1}|-| \rho+r_{2}||=\left|r_{1}-r_{2}\right|$ 
$\left(|| O S_{1}|-| O S_{2}||=|| \rho-r_{1}|-| \rho-r_{2}||=\left|-r_{1}+r_{2}\right|=\left|r_{1}-r_{2}\right|\right)$, iz čega slijedi $O \in H_{1}$. Ako $c$ dodiruje $k_{1}$ izvana (iznutra), a $k_{2}$ iznutra (izvana), onda vrijedi ||$O S_{1}|-| O S_{2}||=|| \rho+r_{1}|-| \rho-r_{2}||=r_{1}+r_{2}$ $\left(|| O S_{1}|-| O S_{2}||=|| \rho-r_{1}|-| \rho+r_{2}||=r_{1}+r_{2}\right)$ pa slijedi $O \in H_{2}$. Dakle, $O \in H_{1} \cup H_{2}$. Analogno se pokaže da vrijedi $O \in H_{3} \cup H_{4}$ i $O \in H_{5} \cup H_{6}$. Zaključujemo da je $O \in\left(H_{1} \cup H_{2}\right) \cap\left(H_{3} \cup H_{4}\right) \cap\left(H_{5} \cup H_{6}\right)$.

Postoji 8 rješenja ovoga problema (4 4) koja se međusobno razlikuju po strani s koje tražena kružnica dira zadane kružnice (s vanjske ili unutarnje strane). U nastavku prikazujemo središta rješenja ovoga Apolonijeva problema reda 3 (zapravo originalnoga Apolonijeva problema) kao presjek odgovarajućih hiperbola, tj. GMS rješenja 3 Apolonijeva problema reda 2. Na svakoj slici prikazujemo po dva rješenja (slike 19 , 20, 21 i 22 .

U svim ostalim slučajevima, u ovisnosti o međusobnom položaju zadanih kružnica, broj rješenja se mijenja, dok se rješenja konstruiraju na isti način koji je prethodno opisan.

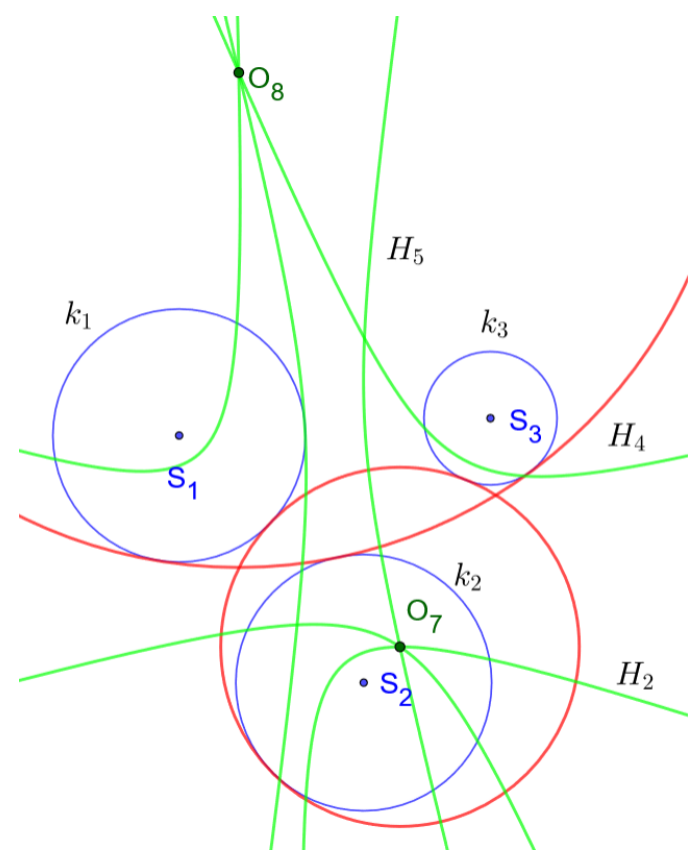

Slika 19 


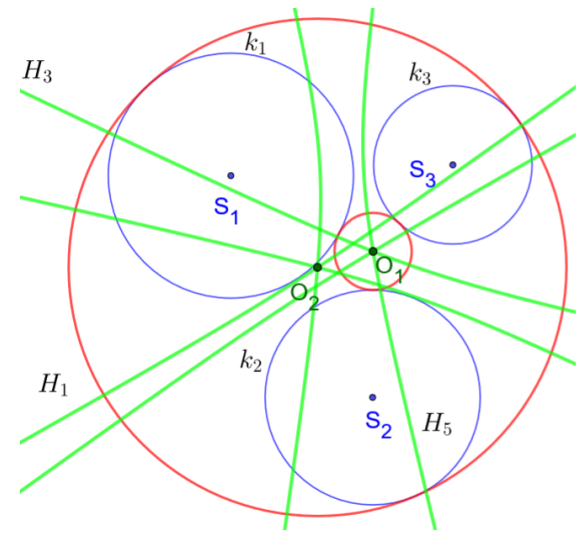

Slika 20

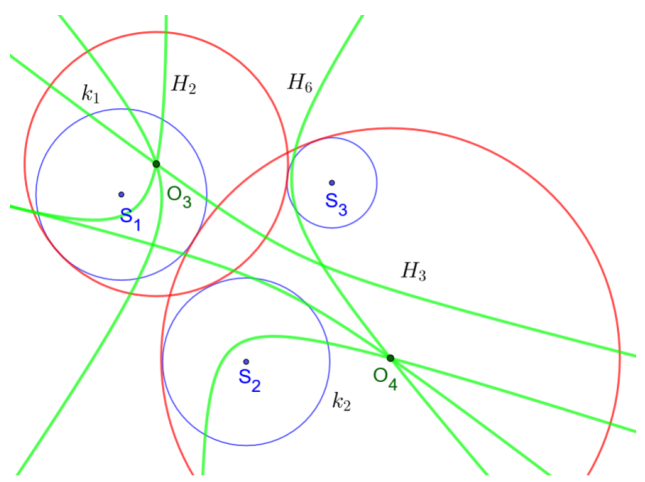

Slika 21

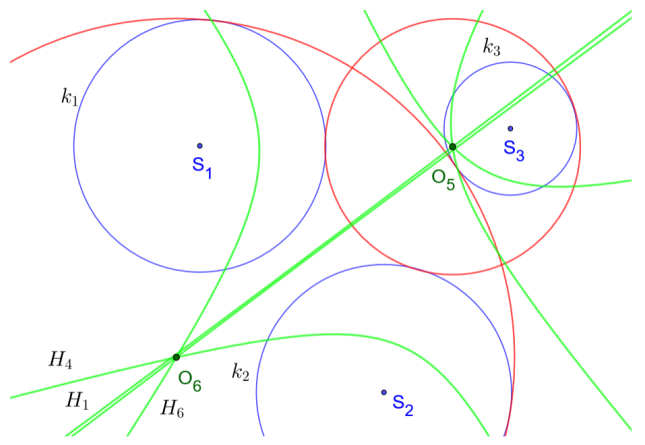

Slika 22 


\section{Apolonijev problem reda $n \geq 4$}

Apolonijevih problema reda 4 ima ukupno petnaest. Najjednostavniji glasi:

Konstruiraj kružnicu koja dodiruje četiri zadane točke.

Budući da zadane točke (ako nikoje 3 nisu kolinearne) određuju četverokut, to rješenje problema postoji ako i samo ako je taj četverokut tetivni. Možemo promatrati također i dužine određene tim točkama kojih ima $\left(\begin{array}{l}4 \\ 2\end{array}\right)=6$. Simetrale tih dužina su GMS kružnica koje dodiruju točke koje određuju tu dužinu (Apolonijev problem reda 2). Očito je sjecište tih simetrala i GMS kružnica koje dodiruju sve četiri zadane točke. Možemo ovaj problem promatrati i kao Apolonijeve probleme reda 3 ako gledamo GMS kružnica koje dodiruju po tri točke. Njih ima $\left(\begin{array}{l}4 \\ 3\end{array}\right)=4$. GMS tih kružnica je samo jedna točka (središte trokutu opisane kružnice), a presjek tih četiriju geometrijskih mjesta središta je neprazan samo ako se sve četiri točke podudaraju i to je središte rješenja sva četiri problema reda 3 i problema reda 4 .

U usporedbi s Apolonijevim problemima nižeg reda gdje smo naišli na konike prilikom određivanja GMS kružnica koje dodiruju zadane objekte, ovdje prilikom promatranja najjednostavnijeg Apolonijeva problema reda 4, dolazimo do najviše jednog rješenja, pa nam stoga, nije interesantno promatrati Apolonijeve probleme reda $n \geq 4$.

\section{Daljnje generalizacije Apolonijeva proble- ma}

Kut presjeka između tražene kružnice i zadanih elemenata (pravca i kružnice) u dosadašnjim razmatranjima je $0^{\circ}$. Stavljajući proizvoljni kut $\alpha \in\left[0,180^{\circ}\right\rangle$ pod kojim tražena kružnica siječe zadane kružnice, odnosno pravce, dobivamo još jednu generalizaciju Apolonijeva problema reda $n$. Analogno, ali znatno složenije, razmatranje možemo provesti i za ovaj problem koristeći metodologiju identičnu onoj koju smo upotrijebili pri rješavanju Apolonijeva problema za $\alpha=0^{\circ}$.

\section{Literatura}

[1] A. Guberina, Generalizacija Apolonijeva problema, diplomski rad, PMF Split, 2018.

[2] N. Koceić Bilan, I. Mirošević, J. Jurko, Različiti nastavno-metodički pristupi čunjosječnicama, math.e 27, 2015. 
[3] N. Koceić Bilan, N. Smajlić, L. Trombetta Burić, Konstruktivna geometrija u nastavi matematike, Osječki matematički list, 2013.

[4] D. Palman, Trokut i kružnica, Element, Zagreb, 1994.

Antonija Guberina

OŠ Tina Ujevića, Šibenik

E-mail adresa: antonijaguberina@gmail.com

Nikola Koceić Bilan

Prirodoslovno-matematički fakultet Sveučilišta u Splitu

E-mail adresa: koceic@pmfst.hr 